\title{
The influence of climate change on the life insurance in the EU: A panel data approach
}

\author{
Oleksandr Melnychenko ${ }^{1,2 *}$, Tetyana Kalna-Dubinyuk ${ }^{3}$, Olha Vovchak $^{4}$, and Tetiana \\ Girchenko ${ }^{4}$ \\ ${ }^{1}$ The London Academy of Science and Business, London, W1U 6TU, United Kingdom \\ ${ }^{2}$ Gdansk University of Technology, Department of Finance, 80-233 Gdansk, Poland \\ ${ }^{3}$ National University of Life and Environmental Sciences of Ukraine, Tourism and Extension \\ Department, 03041 Kyiv, Ukraine \\ ${ }^{4}$ University of Banking, Department of Banking and Financial Technology, 79007, Lviv, Ukraine
}

\begin{abstract}
The financial sector, as one of the most sensitive economic sectors, is alert to all trends and changes in the environment. The aim of the article is to study the impact of climate change on the life insurance market using panel data from 28 countries of the European Union (EU) for the last 9 years. This study is based on a panel model, where the amount of premiums under life insurance contracts is defined as a function of the fundamental factor of climate change - greenhouse gas emissions. According to empirical findings, an increase in greenhouse gas emissions per thousand tons leads to an increase in the amount of life insurance premiums by 0.1786 million euros. It has also been found that an increase in greenhouse gas emissions per thousand tons leads to an increase in deaths in the European Union by 1.0442 people, and these consequences are statistically significant. In general, our results suggest that the life insurance market as well as the nonlife insurance market is dependent on climate change. The empirical results of this study provide valuable insight into how greenhouse gas emissions affect mortality in the European Union.
\end{abstract}

\section{Introduction}

The European Union takes into consideration five major disaster risks: floods, extreme weather activities such as heat, industrial and nuclear accidents, and forest fires. Other risks that receive significant attention include epidemics, critical infrastructure disruptions, terrorism, cyber threats, seismic risks, and animal and plant diseases [1]. The former are those related to climate change. This is a wide range of local, regional and global changes in average weather patterns, mainly due to human activity over the last 100 years [2]. These changes cause structural and other swings in various fields of society, in particular, the financial sector, which is one of the first to respond to global challenges. Thus, recent events related to the spread of coronavirus disease (COVID-19) have clearly demonstrated that all markets around the world have reacted with different in value, but clearly significant changes in financial figures [3-12]. An important part of the financial sector of the economy is the

* The corresponding author: o.melnychenko@london-asb.co.uk 
insurance sector, which is integral to financial stability as a whole [13]. Insurance consists of two main subgroups: non-life insurance and life insurance. Non-life insurance commonly has short-term contracts while life insurance has long-term contracts [14-16]. Life insurance is a contract between a client and an insurer under which the insurer pays benefits to the clients after their death or extension of life in exchange for a premium. With non-life insurance, an insurance policy to cover property risks is issued [17]. Life insurance can be understood as a long-term investment that requires periodic payments. This type of insurance is targeted at policyholders who want to prevent an economic catastrophe for their dependents when they die [18] or to provide for old age if they will be alive when the contract expires. Thus, it serves not only as the protection of the life cycle, but also provides the potential of accumulating cash value for the future [19] with the aim to achieve an acceptable level of financial security [20]. To that end, the product is often sold as a cost-saving or investment method.

Non-life insurance embraces property insurance for a short period (usually one year) and provides protection against loss [21]. The functioning of certain sectors of the economy, such as agricultural business, real estate, directly depends on the proper insurance system of weather-related risks [22]. Thereafter, most research on insurance focuses on characterizing the relations between non-life insurance and climate change, although environmental changes also have a significant impact on human health and life, as well as on the life insurance market, the relations with which has not been researched that deep yet.

The purpose of this study is to examine the impact of climate change on the life insurance market, basing on the data from a group of 28 EU countries during 2011-2019.

Although the structure and dynamics of life insurance figures vary considerably depending on the EU member state, the EU countries are of great interest for studying these relations, as they show significant differences in the structure of the insurance market as well as in the level of financial development. Knowing that the average level of insurance entering the European domestic market in recent years has been 5.25\% [23], the EU can be divided into clusters, as shown below [24, 25]:

1st cluster: Luxembourg, Ireland, United Kingdom, Denmark, France, Italy. In these countries the average market entrance level is more than $5.25 \%$.

2nd cluster: Sweden, Portugal, Belgium, Germany, Malta, Spain, Finland, Netherlands, Cyprus, Poland, Slovakia, Czechia, Austria, Hungary, Slovenia, Greece. In these countries the average entrance level is less than $5.25 \%$ but more than $1 \%$.

3d cluster: countries with a low entrance level: Estonia, Croatia, Lithuania, Latvia, Romania, Bulgaria. In these countries the entrance level is less than $1 \%$.

This study focuses on the interdependence between climate change and the life insurance market and makes the following contribution to the literature of this area. First, the life insurance market of the European Union in recent years has been researched. It revealed differences in the structure of the insurance market in different EU countries. Secondly, due to the lack of evidence, this study seeks to expand knowledge about the impact of climate change figures on life insurance in the EU. It is important to promote life insurance in order to reduce the risk of financial difficulties, as well as to increase the level of financial security for households by increasing money savings. Life insurance can be a reliable and effective tool for this. As far as the authors know, this article is one of the first to quantify the impact of climate change on the life insurance entrance into the European Union. The empirical results can help insurance companies to take measures for increasing the life insurance market by raising awareness of the impact of climate change on quality of life and the mortality risks which provoke them. Although this study combines with a wealth of literature that seeks to explain the relation between insurance entrance and other socioeconomic figures, it is filling a gap in the literature by focusing on life insurance as a tool for accumulating cash value for the future and achieving an acceptable level of financial security for households. This study uses a significant sample (28 EU Member States) and a time 
period (2011-2019), compared to several previous studies examining both the life insurance and non-life insurance entrance.

\section{The Literature Analysis}

An analysis of recent research shows that the scientific literature most often examines the relationship between non-life insurance and climate change, which seems logical given the objects of insurance. The instant connection between the effects of climate change (floods, hurricanes, fires, droughts) and the risks of damage caused by extreme weather activities (more frequent and intense heat waves, droughts, extreme rainfall, storms and high levels of solar radiation) with significant damage and the expenditures on the restoration of enterprises and households in case of damage or destruction of housing or movable property, crop failure or destruction of agricultural assets [26,27,28,29].

Ranger N. and S. Surminski predict in their study [30] that over the next decade gross nonlife insurance premiums in the BRICS economies can grow from $5.4 \%$ to $12.3 \%$ per year, depending on the country. They also demonstrate that increasing wealth has been an important long-term stimulus of aggregate insurance demand growth in developing countries. Despite the importance of insurance for the financial protection of households from the damage caused by weather activities that adversely affect the welfare and socio-economic situation in the world, few studies have examined the life insurance market in the European context of climate change. For this reason, new evidence on trends in life insurance and predictable behaviour is of crucial importance for the information policy in this area.

Research [31] even focuses attention on the relations between prejudices and farmers' costs of life insurance. The authors argue that households increase their life insurance costs by $18.5 \%$ during the year corresponding to the zodiac sign of the year in which these persons were born, and in other years such an increase does not occur.

Although life expectancy in the world has increased from 80.3 to 83.9 years over the last 20 years (2000 to 2020) [32], which could be an additional stimulus to purchase life insurance policies, there are still exist various barriers for the growth of this market, in particular, related to education, retirement age, single households, age, marriage, lack of dependent children [33], and self-discipline [34,35].

However, the literature does not deny that with climate change, the risks of death from natural disasters also increase. Thus, worldwide, natural disasters have caused an average of $0.1 \%$ of total deaths in the last decade. Approximately 60,000 people die each year as a result of natural disasters. Franzke, C. L. E., and H. Torelló and Sentelles find clear evidence that climate change regimes affect the predisposition and number of deaths [37]. In 2020, 389 natural disasters were reported. The results of these disasters were: 15,080 people killed, 98.4 million people injured and $\$ 171.3$ billion in economic losses. Of these, 41 cases were recorded in Europe, resulting in $42.9 \%$ of all deaths during the mentioned period [39]. One of the most expensive catastrophes in the world was Hurricane Katrina, which cost the insurance industry about 82.4 billion US dollars [40,41]. Research by Mitchell and colleagues [42] finds clear evidence that climate change regimes affect the predisposition and number of deaths on all continents. However, the relation between the increase in climate change risks and the size of life insurance premiums has not been sufficiently studied in modern research, although at first it seems logical to assume that climate change and its effect on quality of human life vary as well as their attitudes to risk management and their insurance through cooperation with insurance companies in this direction.

The aim of this study is to analyse the relations between the size of life insurance premiums in the European Union and climate change figures. 


\section{Data and Methodology}

\subsection{Data}

The analysis is based on an unbalanced data set from 28 countries of the European Union for the period of 2011-2019. The period was chosen based on the availability of all data series. The dependent variable is the amount of life insurance premiums. Independent variables, which are of interest for the purposes of this study, are indicators that are directly related to the effects of climate change: greenhouse gas emissions, temperature deviations, overall mortality rate in the EU and environmental conservation costs (Table 1).

Table 1. Variables used in the analysis of the panel data.

\begin{tabular}{|c|c|c|c|}
\hline Name & Definition & Abbreviation & Source \\
\hline $\begin{array}{c}\text { Total gross } \\
\text { premiums }\end{array}$ & Life insurance gross premiums & PREMIUS & OECD [43] \\
\hline $\begin{array}{c}\text { Greenhouse gas } \\
\text { emissions }\end{array}$ & $\begin{array}{c}\text { Greenhouse gases }(\mathrm{CO} 2, \mathrm{~N} 2 \mathrm{O} \text { in } \\
\text { equivalent, } \mathrm{CHC} \text { in } \mathrm{CO} 2 \\
\text { equivalent, } \mathrm{PFC} \text { in } \mathrm{CO} 2 \\
\text { equivalent, SF6 in CO2 } \\
\text { equivalent, NF3 in CO2 } \\
\text { equivalent) }\end{array}$ & $\begin{array}{c}\text { GGE (Thousand } \\
\text { tonnes) }\end{array}$ & Eurostat [44] \\
\hline $\begin{array}{c}\text { Temperature } \\
\text { deviation }\end{array}$ & $\begin{array}{c}\text { Mean near surface temperature } \\
\text { deviation }\end{array}$ & $\mathrm{TD}\left({ }^{\circ} \mathrm{C}\right)$ & FAOSTAT $[45]$ \\
\hline Fatalities & Deaths in the EU & $\mathrm{F}$ & Eurostat $[46]$ \\
\hline $\begin{array}{c}\text { Expenditure on } \\
\text { environmental } \\
\text { protection }\end{array}$ & $\begin{array}{c}\text { Environmental protection } \\
\text { expenditure accounts }\end{array}$ & $\begin{array}{c}\text { EPEA (million } \\
\text { euro })\end{array}$ & $\begin{array}{c}\text { Eurostat } \\
{[47,48,49]}\end{array}$ \\
\hline
\end{tabular}

Table 2 presents descriptive statistics for a complete unbalanced data set of a panel with 28 countries and 252-time observations. The standard deviation of premiums is 52,994.88, which shows how diverse our life insurance sample is. According to the panel, the lowest premiums are paid in Bulgaria (average for the study period 40.16 million euros), and the highest are in the UK $(231,988.92$ million euros for the same period).

Table 2. Descriptive statistics.

\begin{tabular}{|c|c|c|c|c|c|}
\hline Variable & Obs. & Mean & St. Dev. & Min & Max \\
\hline PREMIUS & 252 & $27,224.75$ & $52,994.88$ & 0.00 & $283,789.44$ \\
\hline $\begin{array}{c}\text { GGE (Thousand } \\
\text { tonnes) }\end{array}$ & 252 & $160,837.70$ & $214,224.73$ & 2279.56 & $966,107.30$ \\
\hline TD $\left({ }^{\circ} \mathrm{C}\right)$ & 252 & $182,542.92$ & $229,598.91$ & 3236.00 & $954,874.00$ \\
\hline F & 252 & 1.67 & 0.57 & 0.37 & 2.72 \\
\hline EPEA & 252 & 6952.08 & $11,863.89$ & 0.00 & $54,388.00$ \\
\hline
\end{tabular}

Source: calculated by the authors.

Table 3 presents the correlation matrix of dependent and independent variables. There is a significant correlation between life insurance premiums and greenhouse gas emissions, the number of deaths, the average temperature deviation and the environmental conservation costs. Also, simple relations between model variables show that greenhouse gas emissions are strongly correlated with the number of deaths in the EU. 
Table 3. A correlation matrix.

\begin{tabular}{|c|c|c|c|c|c|}
\hline & PREMIUS & GGE & F & TD & EPEA \\
\hline PREMIUS & 1 & & & & \\
\hline GGE & 0,722227 & 1 & & & \\
\hline F & 0,747745 & 0,974313 & 1 & & \\
\hline TD & $-0,2295$ & $-0,12268$ & $-0,09253$ & 1 & \\
\hline EPEA & 0,667356 & 0,86541 & 0,86 & $-0,09109$ & 1 \\
\hline
\end{tabular}

Source: calculated by the authors.

\subsection{Methodology}

The size of the premium under life insurance contracts in this study is defined as a function of greenhouse gas emissions as follows:

$$
\text { PREMIUS }_{\mathrm{i}, \mathrm{t}}=\mathrm{b}_{0}+\mathrm{b}_{1} * \mathrm{GGE}_{\mathrm{i}, \mathrm{t}}+\varepsilon_{\mathrm{i}, \mathrm{t}}
$$

where countries are denoted by the index $\mathrm{i}(\mathrm{i}=1, \ldots, \mathrm{N})$; the period of time is denoted by the index $\mathrm{t}(\mathrm{t}=1, \ldots, \mathrm{T})$; $\mathrm{b} 1$ is the regression coefficient estimated by regression analysis. It shows that as long as other variables remain fixed, an increase of the explanatory variable in one unit increases (or decreases) the amount of premiums under life insurance contracts by $b$ units. $\varepsilon_{\mathrm{i}, \mathrm{t}}$ is a member of the random error, which covers all factors that affect the amount of premiums, but are not included in the variables of the model specification.

A positive reaction between the growing effects of climate change and the amount of premiums for life insurance contracts in the European Union is expected. Based on the latest literature, the following hypothesis is tested:

A hypothesis: There is a positive relation between the growing effects of climate change and the amounts of life insurance in the European Union.

The model in equation (1) presents a general specification aimed to study the role of climate change figures in the life insurance market, where the amount of premiums is considered as a dependent variable while greenhouse gas emissions are considered as an explanatory variable.

To identify the dependence of the life insurance market on climate change a regression analysis model will be used. There are conducted tests at the EU country level using the panel data.

Since the correlation matrix (Table 3 ) also shows relations between the number of deaths and greenhouse gas emissions, it will also be analysed. Thus, the number of deaths in the EU (F) is considered as a function of greenhouse gas emissions as follows:

$$
\mathrm{F}_{\mathrm{i}, \mathrm{t}}=\mathrm{b}_{0}+\mathrm{b}_{1} * \mathrm{GGE}_{\mathrm{i}, \mathrm{t}}+\varepsilon_{\mathrm{i}, \mathrm{t}}
$$

where countries are denoted by the index $i(i=1, \ldots, N)$; the period of time is denoted by the index $t(t=1, \ldots, T)$; $b_{1}$ is the regression coefficient estimated by regression analysis. It shows that as long as other variables remain fixed, increasing the explanatory variable by one unit increases (or decreases) the number of deaths by $b$ units. $\varepsilon_{\mathrm{i}, \mathrm{t}}$ - a member of the random error, covering all factors that affect the number of deaths, but are not included in the variables of the model specification.

\section{Empirical Results}

Table 4 shows the results of the base specification mentioned in section 2. According to the panel model, an increase in greenhouse gas emissions per thousand tonnes leads to an 
increase in life insurance premiums of 0.1786 million euros and this effect is statistically significant at $0 \%$.

Table 4. Empirical results of the impact of greenhouse gas emissions on the amount of life insurance premiums.

\begin{tabular}{|c|c|}
\hline & PREMIUS \\
\hline GGE & $\begin{array}{c}0.1786^{*} \\
(0.0108)\end{array}$ \\
\hline R-squared & 0.5216 \\
\hline Total panel (unbalanced) observations & 252 \\
\hline
\end{tabular}

Source: Research results.

Notes: Standard error in parentheses; ${ }^{*} \mathrm{p}<0.0001$.

Table 5 shows the results of the basic specification mentioned in section 2. According to the panel model, an increase in greenhouse gas emissions per thousand tonnes leads to an increase in deaths in the European Union by 1.0442 people and this effect is statistically significant at $0 \%$.

Table 5. Empirical results of the impact of greenhouse gas emissions on the number of deaths.

\begin{tabular}{|c|c|}
\hline & PREMIUS \\
\hline GGE & $\begin{array}{c}1.0442 * \\
(0.0152)\end{array}$ \\
\hline R-squared & 0.9492 \\
\hline Total panel (unbalanced) observations & 252 \\
\hline
\end{tabular}

Source: Research results.

Notes: Standard error in parentheses; ${ }^{*} \mathrm{p}<0.0001$.

The reliability of conclusions is verified by running models on sub-samples formed by the EU countries in accordance with clusters 1 and 2 listed in section 1. Countries in cluster 3 have a low level of life insurance entrance, so it should not be used to test the model because life insurance market indicators are not representative. The results are presented in table 6 and confirm the previous conclusions. In general, these results show that climate change is affecting the development of the life insurance market and the size of premiums under life insurance contracts at the level of $0 \%$ significance.

Table 6. A reliability check - an updated model.

\begin{tabular}{|c|c|c|}
\hline & PREMIUS - cluster 1 & PREMIUS - cluster 2 \\
\hline GGE & $\begin{array}{c}0.311909^{*} \\
(0.0212)\end{array}$ & $\begin{array}{c}0.0885^{*} \\
(0.0037)\end{array}$ \\
\hline R-squared & 0.8058 & 0.7934 \\
\hline Total panel (unbalanced) observations & 54 & 144 \\
\hline
\end{tabular}

Source: Research results.

Notes: Standard error in parentheses; ${ }^{*} \mathrm{p}<0.0001$

\section{Conclusions}

The aim of the article was to study the impact of climate change on the development of the life insurance market in the European Union using panel data from $28 \mathrm{EU}$ countries for the 
period of 2011-2019. Four factors were considered: greenhouse gas emissions, temperature deviations, overall mortality rate in the EU, and environmental conservation costs.

The results of the panel model highlight the significant positive relations between greenhouse gas emissions and the size of premiums for life insurance contracts. It seems logical, because climate change and the impact of its effects on quality of human life changes their attitude to risk management and focuses their attention on insurance through cooperation with insurance companies in this direction.

According to empirical findings, an increase in greenhouse gas emissions per thousand tons leads to an increase in the amount of life insurance premiums by 0.1786 million euros. It has also been found that an increase in greenhouse gas emissions per thousand tonnes leads to an increase in deaths in the European Union by 1.0442 people, and these consequences are statistically significant. This means, for instance, that increasing Bulgaria's average greenhouse gas emissions to European Union averages could lead to an additional 98,019 deaths in that country.

In general, our results suggest that the life insurance market as well as the non-life insurance market is dependent on climate change.

Considering these findings, it is suggested to draw households' attention to maintaining the concept of sustainable development and to inform them about the possibilities of ensuring financial security due to life insurance mechanisms [50].

Empirical results provide a valuable insight into how greenhouse gas emissions affect mortality in the European Union to provide consumers with cost-effective options, with the ultimate goal of expanding life insurance services. As far as we know, this work is the first study of the relation between climate change and the development of the life insurance market in the European Union. It is also an extremely important issue in the longer term, considering current trends and the EU's desire to reduce climate change risks [51-111].

This study is not devoid of limitations. First, the findings of this study are limited to the data on which the results are based. Second, the analysis uses a limited number of variables that determine climate change. This research to compromise between the explanatory variables and the full availability of data for the sample of countries. Future research should include other variables that affect climate change. The research should be conducted as soon as the data are available over time.

\section{References}

1. The European Commission publishes the new report on disaster risks in the EU. URL: https://ec.europa.eu/echo/news/european-commission-publishes-new-report-disasterrisks-eu_en (accessed on 10 July 2021)

2. N.L. Bindoff, P.A. Stott, K.M. AchutaRao, M.R. Allen, N. Gillett, D. Gutzler, K. Hansingo, G. Hegerl, et al., Chapter 10 -Detection and attribution of climate change: From global to regional. In: Climate Change 2013: The Physical Science Basis. IPCC Working Group I Contribution to AR5. Cambridge: Cambridge University Press (2013)

3. U. Vatamanyuk-Zelinska, O. Melnychenko, Problems and Perspectives in Management, 18(3), 11-27 (2020). http://dx.doi.org/10.21511/ppm.18(3).2020.02

4. M. Arif, M. Hasan, S. M.Alawi, M.A. Naeem, Global Finance Journal, 49, 100650 (2021). https://doi.org/10.1016/j.gfj.2021.100650

5. H.Ö. Dursun-de Neef, A. Schandlbauer, Journal of Banking \& Finance, 106236 (2021). https://doi.org/10.1016/j.jbankfin.2021.106236

6. I. Hasan, P. N.Politsidis, Z. Sharma, Journal of Banking \& Finance, 106121 (2021). https://doi.org/10.1016/j.jbankfin.2021.106121 
7. O. Melnychenko, Energies, 14(1), 210 (2021). https://doi.org/10.3390/en14010210

8. A. Moretto, F. Caniato Can, Journal of Purchasing and Supply Management, 100713 (2021). https://doi.org/10.1016/j.pursup.2021.100713

9. J. W. Goodell, Finance Research Letters, 35, 101512 (2020). https://doi.org/10.1016/j.frl.2020.101512

10. J. J. Szczygielski, A. Charteris, P. R. Bwanya, J. Brzeszczyński, International Review of Financial Analysis, 101837 (2021). https://doi.org/10.1016/j.irfa.2021.101837

11. D. Zhang, M. Hu, Q. Ji, Finance Research Letters, 36, 101528 (2020). https://doi.org/10.1016/j.frl.2020.101528

12. M. Zheng, Finance Research Letters, 102151 (2021). https://doi.org/10.1016/j.frl.2021.102151

13. B. Diallo, A. Al-Mansour, Research in International Business and Finance, 42, 224232 (2017). https://doi.org/10.1016/j.ribaf.2017.04.024

14. M. Balcilar, R. Gupta, Ch.-Ch. Lee, G. Olasehinde-Williams, Research in International Business and Finance, 54, 101253 (2020). https://doi.org/10.1016/j.ribaf.2020.101253

15. E. Flores, J.V.F. Carvalho, J.O. Sampaio, Research in International Business and Finance, 58, 101444 (2021). https://doi.org/10.1016/j.ribaf.2021.101444

16. A. Möhlmann, Financial Management, 1-26 (2020). https://doi.org/10.1111/fima.12305

17. M. Dickson, H. Hardy, H. R. Waters, Actuarial Mathematics for Life Contingent Risks, Seconded (Cambridge University Press, Cambridge, 2009). https://doi.org/10.1017/CBO9780511800146

18. H. Fang, Z. Wu, Journal of Economic Theory, 189, 105093 (2020). https://doi.org/10.1016/j.jet.2020.105093

19. A. G. Rabbani, Journal of Behavioral and Experimental Finance, 27, 100385 (2020). https://doi.org/10.1016/j.jbef.2020.100385

20. O. Melnychenko, Journal of Risk and Financial Management, 13(9), 191 (2020). https://doi.org/10.3390/jrfm13090191

21. B. Wason, R.D. Hill, The Insurance Industry in Economic Development (New York University Press, New York, 1986)

22. E. Doherty, S. Mellett, D. Norton, T. K. J. McDermott, D. O’Hora, M. Ryan, Journal of Environmental Management, 290, 112607 (2021). https://doi.org/10.1016/j.jenvman.2021.112607

23. Total premiums to GDP ratio as insurance penetration measure on the domestic market in Europe from 2004 to 2019. URL: https://www.statista.com/statistics/433054/insurance-premiums-to-gdp-ratio/_(2019)

24. C. Gaganis, I. Hasan, F. Pasiouras, Economic Modelling, 89, 256-272 (2020). https://doi.org/10.1016/j.econmod.2019.10.024

25. T. Beck, I. Webb, Economic, demographic, and institutional determinants of life insurance consumption across countries. World Bank Econ. Rev., 17, 51-88 (2003)

26. C. Cannon, K. F. Gotham, K. Lauve-Moon, B. Powers, Climate Risk Management, 27, 100210 (2020). https://doi.org/10.1016/j.crm.2019.100210

27. A. Ivčević, V. Statzu, A. Satta, R. Bertoldo, International Journal of Disaster Risk Reduction, 52, 101956 (2021). https://doi.org/10.1016/j.ijdrr.2020.101956

28. A. Leblois, T. Le Cotty, E. Maître d'Hôtel, Ecological Economics, 176, 106716 (2020). https://doi.org/10.1016/j.ecolecon.2020.106716 
29. F. Crick, K. Jenkins, S. Surminski, Science of the Total Environment, 636, 192-204 (2018). https://doi.org/10.1016/j.scitotenv.2018.04.239

30. N. Ranger, S. Surminski, International Journal of Disaster Risk Reduction, 3, 14-30 (2013). https://doi.org/10.1016/j.ijdrr.2012.11.004

31. Y. Liu, Y. Zhang, X. Chen, Y. Yang, Economics Letters, 206, 109975 (2021). https://doi.org/10.1016/j.econlet.2021.109975

32. M.R. Islam, S. Liu, R. Biddle, I. Razzak, X. Wang, P. Tilocca, G. Xu, Technological Forecasting and Social Change, 163, 120486 (2021). https://doi.org/10.1016/j.techfore.2020.120486

33. A. Strzelecka, A. Kurdyś-Kujawska, D. Zawadzka, Procedia Computer Science, 176, 3407-3417 (2020). https://doi.org/10.1016/j.procs.2020.09.056

34. A.G. Rabbani, Journal of Behavioral and Experimental Finance, 27, 100385 (2020). https://doi.org/10.1016/j.jbef.2020.100385

35. I. Shkodina, O. Melnychenko, M. Babenko, Financial and Credit Activity: Problems of Theory and Practice, 2(33), 513-521 (2020). http://dx.doi.org/10.18371/fcaptp.v2i33.207223

36. H. Ritchie, M. Roser, Natural Disasters. Published online at OurWorldInData.org. (2014) URL: https://ourworldindata.org/natural-disasters (accessed on 10 July 2021)

37. C.L.E. Franzke, H. Torelló i Sentelles, Climatic Change, 162, 507-525 (2020). https://doi.org/10.1007/s10584-020-02825-z

38. Disaster Year in Review 2020 Global Trends and Perspectives. URL: https://cred.be/sites/default/files/CredCrunch62.pdf (accessed on 10 July 2021)

39. The Non-Covid year in disasters: Global trends and perspectives. URL: https://dial.uclouvain.be/pr/boreal/en/object/boreal\%3A245181/datastream/PDF_01/vie w (accessed on 10 July 2021)

40. Global number of deaths from natural disasters 2000-2020. URL: https://www.statista.com/statistics/510952/number-of-deaths-from-natural-disastersglobally/ (accessed on 10 July 2021)

41. Most costly catastrophes to the insurance industry worldwide from 1970 to 2017. URL: https://www.statista.com/statistics/267210/natural-disaster-damage-totals-worldwidesince-1970/ (accessed on 10 July 2021)

42. D. Mitchell, C. Heaviside, S. Vardoulakis, C. Huntingford, G. Masato, B. P. Guillod, P. Frumhoff, A. Bowery, D. Wallom, M. Alle, Environ Res Lett 11(7), 074006 (2016)

43. Insurance indicators. URL:

https://stats.oecd.org/viewhtml.aspx?datasetcode=INSIND\&lang=en (accessed on 10 July 2021)

44. Greenhouse gas emissions by source sector. URL:

http://appsso.eurostat.ec.europa.eu/nui/show.do?dataset=env_air_gge\&lang=en (accessed on 10 July 2021)

45. Temperature change. URL: http://www.fao.org/faostat/en/\#data/ET (accessed on 10 July 2021)

46. Population change - Demographic balance and crude rates at national level. Deaths total. URL:

https://ec.europa.eu/eurostat/databrowser/view/demo_gind/default/table?lang=en (accessed on 10 July 2021)

47. Production of environmental protection services of general government by economic characteristics. URL: 
https://ec.europa.eu/eurostat/databrowser/view/env_ac_pepsgg/default/table?lang=en (accessed on 16 July 2021)

48. Production of environmental protection services of corporations as specialist producers by economic characteristics. URL:

https://ec.europa.eu/eurostat/databrowser/view/env_ac_pepssp/default/table?lang=en (accessed on 16 July 2021)

49. Production of environmental protection services of corporations other than specialist producers by economic characteristics and NACE Rev. 2 activity. URL:

https://ec.europa.eu/eurostat/databrowser/view/env_ac_pepsnsp/default/table?lang=en (accessed on 16 July 2021)

50. R. Kostyrko, T. Kosova, L. Kostyrko, L. Zaitseva, O. Melnychenko, Energies, 14, 5080 (2021)

51. S. Cyfert, A. Chwiłkowska-Kubala, W. Szumowski, R. Miśkiewicz, PLoS ONE, 16(4), e0249724 (2021)

52. B. Czyżewski, A. Matuszczak, R. Miskiewicz, Technological and Economic Development of Economy, 25(1), 82-102 (2019)

53. H. Dzwigol, M. Dzwigol-Barosz, R. Miskiewicz, A. Kwilinski, Entrepreneurship and Sustainability Issues, 7(4), 2630-2644 (2020)

54. H. Dzwigol, M. Dzwigol-Barosz, Z. Zhyvko, R. Miskiewicz, H. Pushak, Journal of Security and Sustainability Issues, 8(3), 307-317 (2019)

55. E. Gross-Golacka, M. Kusterka-Jefmanska, R. Miskiewicz, B. Jefmanski, A. Rzepka, T. Kupczyk, European Research Studies Journal, XXIV(2B), 410-429 (2021)

56. R. Miskiewicz, Polityka Energetyczna, 21(2), 49-62 (2018)

57. R. Miskiewicz, Virtual Economics, 2(2), 37-47 (2019)

58. R. Miskiewicz, Marketing and Management of Innovations, 3, 371-381 (2020)

59. R. Miskiewicz, Energies, 13(22), 6106 (2020)

60. R. Miśkiewicz, Journal of Risk and Financial Management, 14(2), 59 (2021)

61. R. Miśkiewicz, R. Wolniak, Sustainability, 12(14), 5776 (2020)

62. K. Pająk, O. Kvilinskyi, O. Fasiecka, R. Miskiewicz, Economics and Environment, 2(61), 122-138 (2017)

63. A. Rzepka, R. Borowiecki, R. Miskiewicz, Z. Olesinski, European Research Studies Journal, XXIV(2), 1149-1162 (2021)

64. P.W. Saługa, K. Szczepańska-Woszczyna, R. Miśkiewicz, M. Chłąd, Energies, 13(18), 4833 (2020)

65. H. Dzwigol, M. Dźwigoł-Barosz, A. Kwilinski, International Journal of Entrepreneurship, 24(1), 1-5 (2020)

66. Y. Kharazishvili, A. Kwilinski, O. Grishnova, H. Dzwigol, Sustainability, 12(21), 8953 (2020)

67. Y. Kharazishvili, A. Kwilinski, O. Sukhodolia, H. Dzwigol, D. Bobro, J. Kotowicz, Energies, 14(8), 2126 (2021)

68. Y. Kharazishvili, A. Kwilinski, H. Dzwigol, V. Liashenko, Virtual Economics, 4(2), 7 40 (2021)

69. A. Kwilinski, O. Vyshnevskyi, H. Dzwigol, Journal of Risk and Financial Management, 13(7), 142 (2020) 
70. O. Lyulyov, T. Pimonenko, A. Kwilinski, H. Dzwigol, M. Dzwigol-Barosz, V. Pavlyk, P. Barosz, Energies, 14(2), 373 (2021)

71. O. Lyulyov, I. Vakulenko, T. Pimonenko, A. Kwilinski, H. Dzwigol, M. DzwigolBarosz, Energies, 14(12), 3497 (2021)

72. A. Kwilinski, H. Dzwigol, V. Dementyev, International Journal of Entrepreneurship, 24(1 Special Issue), 1-5 (2020)

73. O. Arefieva, O. Polous, S. Arefiev, V. Tytykalo, A. Kwilinski, IOP Conference Series: Earth and Environmental Science, 628, 012039 (2021)

74. V. Boiko, A. Kwilinski, M. Misiuk, L. Boiko, Economic Annals-XXI, 175(1-2), 68-72 (2019)

75. S. Bogachov, A. Kwilinski, B. Miethlich, V. Bartosova, A. Gurnak, Entrepreneurship and Sustainability Issues, 8(2), 487-499 (2020)

76. O. Chygryn, Y. Bilan, A. Kwilinski, Marketing and Management of Innovations, 3, 356-368 (2020)

77. V.V. Dementyev, A. Kwilinski, Journal of Institutional Studies, 12(1), 100-116 (2020)

78. V. Koibichuk, N. Ostrovska, F. Kashiyeva, A. Kwilinski, Marketing and Management of Innovations, 1, 253-265 (2021)

79. V. Kondratenko, O. Okopnyk, L. Ziganto, A. Kwilinski, Marketing and Management of Innovations, 1, 87-94 (2020)

80. A. Kuzior, A. Kwilinski, V. Tkachenko, V. Entrepreneurship and Sustainability, 7(2), 1353-1376 (2019)

81. A. Kuzior, A. Kwilinski, I. Hroznyi, Energies, 14(9), 2572 (2021)

82. A. Kuzior, O. Lyulyov, T. Pimonenko, A. Kwilinski, D. Krawczyk, Sustainability, 13(15), 8145 (2021)

83. A. Kwilinski, Virtual Economics, 1(1), 7-25 (2018)

84. A. Kwilinski, Marketing and Management of Innovations, 4, 116-128 (2018)

85. A. Kwilinski, Academy of Accounting and Financial Studies Journal, 23(SI2), 1-6 (2019)

86. A. Kwilinski, V. Tkachenko, A. Kuzior, Journal of Security and Sustainability Issues, 9(2), 561-570 (2019)

87. A. Kwilinski, N. Dalevska, S. Kravchenko, I. Hroznyi, I. Kovalenko, Journal of Entrepreneurship Education, 22(SI1), 1-7 (2019)

88. A. Kwilinski, I. Ruzhytskyi, V. Patlachuk, O. Patlachuk, B. Kaminska, Journal of Legal, Ethical and Regulatory Issues, 22(SI2), 1-6 (2019)

89. A. Kwilinski, R. Volynets, I. Berdnik, M. Holovko, P. Berzin, P. Journal of Legal, Ethical and Regulatory Issues, 22(SI2), 1-6 (2019)

90. A. Kwilinski, K. Pajak, O. Halachenko, S. Vasylchak, Y. Pushak, P. Kuzior, Marketing and Management of Innovations, 4, 172-181 (2019)

91. A. Kwilinski, A. Kuzior, Management Systems in Production Engineering, 28(2), 119$123(2020)$

92. A. Kwilinski, Y. Zaloznova, N. Trushkina, N. Rynkevych, E3S Web of Conferences, 168, $00031(2020)$

93. A. Kwilinski, M. Dielini, O. Mazuryk, V. Filippov, V. Kitseliuk, Journal of Security and Sustainability Issues, 10(1), 345-358 (2020) 
94. A. Kwilinski, D. Shteingauz, V. Maslov, Financial and Credit Activities: Problems of Theory and Practice, 3(34), 133-140 (2020)

95. A. Kwilinski, I. Slatvitskaya, T. Dugar, L. Khodakivska, B. Derevyanko, International Journal of Entrepreneurship, 24(1 Special Issue), 1-8 (2020)

96. A. Kwilinski, V. Litvin, E. Kamchatova, J. Polusmiak, D. Mironova, International Journal of Entrepreneurship, 25(1), 1-8 (2021)

97. Y. Kyrylov, V. Hranovska, V. Boiko, A. Kwilinski, L. Boiko, L. Journal of Risk and Financial Management, 13(12), 303 (2020)

98. V. Lakhno, V. Malyukov, T. Bochulia, Z. Hipters, A. Kwilinski, O. Tomashevska, International Journal of Civil Engineering and Technology, 9(8), 1802-1812 (2018)

99. O. Lyulyov, T. Pimonenko, A. Kwilinski, Y. Us, E3S Web of Conferences, 250, 03006 (2021)

100.K. Pająk, B. Kamińska, O. Kvilinskyi, O. Financial and Credit Activity: Problems of Theory and Practice, 2(21), 204-217 (2016)

101.T. Savchenko, N. Basiurkina, O. Rodina, A. Kwilinski, Management Theory and Studies for Rural Business and Infrastructure Development, 41(1), 43-61 (2019)

102.V. Tkachenko, A. Kwilinski, O. Korystin, N. Svyrydiuk, I. Tkachenko, Journal of Security and Sustainability, 8(3), 375-385 (2019)

103.V. Tkachenko, A. Kwilinski, M. Klymchuk, I. Tkachenko, Management Systems in Production Engineering, 27(2), 119-123 (2019)

104.V. Tkachenko, A. Kwilinski, I. Tkachenko, P. Puzyrova, Marketing and Management of Innovations, 2, 228-238 (2019)

105.V. Tkachenko, A. Kwilinski, B. Kaminska, I. Tkachenko, P. Puzyrova, Financial and Credit Activity: Problems of Theory and Practice, 3(30), 85-94 (2019)

106.V. Tkachenko, A. Kuzior, A. Kwilinski, Journal of Entrepreneurship Education, 22(6), 1-10 (2019)

107.L. Karpenko, M. Serbov, A. Kwilinski, V. Makedon, S. Drobyazko, Academy of Strategic Management Journal, 17(5), 1-7 (2018)

108.J. Polcyn, Sustainability, 13(15), 6846 (2021)

109.R. Abazov, Herald of Journalism, 58(4), 34-43 (2021)

110.O. Melnychenko, Virtual Economics, 2(3), 30-40 (2019)

111.O. Burlaka, A. Kuzior, O. Hanych, S. Kravchenko, O. Melnychenko, Journal of Legal, Ethical and Regulatory Issues, 22(Special Issue 2), 1-5 (2019) 